\title{
The Development of the Rolling Stock Industry in Prewar Japan
}

\author{
Minoru SAWAI \\ Osaka University
}

7 HE PURPOSE OF this article is to study the special characteristics of the process by which the rolling stock industry in Japan develI oped from the Meiji period up to the years of the Pacific War. The biggest feature distinguishing Japan's machine industry in the postwar period of high growth from that industry in the prewar period would probably be the fact that the former's development was led by a mass-production-type of machine industry founded on a market (anticipation) production represented by the two categories of large durable consumer goods, the automobile and electrical whitegoods. In prewar times, however, the type of machine industry that continued to occupy the mainstream of the private machine industry was basically one in which, in response to an order, capital goods were produced either one at a time or in small lots (though sometimes this approach was combined with market production). In this sense, even though the same phrase, "Japan's industrialization," may be used for both periods, we need to be aware of the difference between the postwar type of catch-up industrialization that experienced growth in the durable consumer goods sector and the prewar type of catch-up 
industrialization that did not have such an experience. ${ }^{1}$

Of course, the existence of huge producers like the military arsenals and naval dockyards had a decisive impact on the way the private machine industry developed from the Meiji period, and during the period between the two world wars progress was made in light machinery based on market production, such as sewing machines, optical instruments like cameras, and watches; in addition, in the lead-up to World War II and during it, rapid growth was seen in the automotive and aircraft industries. Still, a mass production system founded on a market production geared for an indeterminately large number of customers, of the kind symbolized by the Ford Motor Company's Model $\mathrm{T}$ production, never eventuated in prewar Japan. ${ }^{2}$

In recent economic history and business history studies in the West, a new interest has been awakened in the historical significance of other things besides the mass production system and the mass sales system: batch production, custom production, and craft production. ${ }^{3}$ Following on from this new trend, John $\mathrm{K}$. Brown, in his detailed research on the Baldwin Locomotive Works, which was the largest manufacturer of locomotives in the United States, urges us to keep in mind the differences and similarities between the two formats of produc-

${ }^{1}$ Tetsurō Nakaoka, "Hatten tojōkoku kikai kōgyō no gijutsu keisei-senmon bungyō to shijō no mondai o megutte" [Technological formation of machine industries in developing countries: On the problems of division of labor by specialty and market], in Yukiharu Takeoka, Hideyuki Takahashi, and Tetsurō Nakaoka, eds., Shingijutsu no dōnyū-kindai kikai kōgyō no hatten [The introduction of new technology: The development of modern machine industries] (Tokyo: Döbunkan, 1993).

${ }^{2}$ For more on the establishment of the mass production system in the United States, see David A. Hounshell, From the American System to Mass Production, 1800-1932: The Development of Manufacturing Technology in the United States (Baltimore: Johns Hopkins University Press, 1984).

${ }^{3}$ Representative of such research is Michel J. Piore and Charles F. Sabel's /The Second Industrial Divide/ (New York: Basic Books, 1984); it discusses "flexible specialization," a new approach to manufacturing that is well suited to small-lot, wide-variety production rather than to "mass production"; the political and social conditions conducive to this type of approach; small firms, the successors to the tradition of craftsmanship; and the local communities that nurture such small firms. A recent important work that tries to classify the United States production mode around the period 1870-1930 into four types of production-custom, batch, bulk, and mass-on the basis of user class and producer formats, is Philip Scranton's Endless Novelty: Specialty Production and American Industrialization, 1865-1915 (Baltimore: Johns Hopkins University Press, 1997). 
tion in the machine industry: building and manufacturing. His basic argument is that, even though the world of "building," which lays its foundation upon order production as typified by the making of such things as machine tools, locomotives, and ships, and the world of typical anticipation "manufacturing," which is involved in making such light machinery as small arms, sewing machines, typewriters, and bicycles, both join together to make up the machine industry, the two worlds are very different, and not only because their production methods differ. According to him, each world also differs in the relationship between the manufacturer and the customer/user, in product innovation, in business management systems, in sales strategies, in equipment machinery, and in the nature of the labor force employed, and the "building" world in particular constructed a flexible production system that responded to market trends. ${ }^{4}$ Fordism may truly be described as the highest point reached by the "manufacturing" stream in America during the period between the two world wars.

The mainstream of the prewar machine industry in Japan, a catchup industrial country, was of the building type, based as it was on order production. Even the bicycle industry, ${ }^{5}$ which in America was a direct forerunner of the appearance of the automobile industry, in Japan evolved its own special production system-one that, if anything, closely approximated that of many items of general merchandise for export. ${ }^{6}$ Thus the process of raising the level of Japan's machine industry before the war was one of moving from a technological and managerial accumulation of experience in an order-production-type, building-type machine industry and a production system classically seen in the bicycle industry, to the birth from that seedbed of new industries like the automobile and even the aircraft manufacturing industries.

${ }^{4}$ See John K. Brown, The Baldwin Locomotive Works, 1831-1915 (Baltimore: Johns Hopkins University Press, 1995). An important work on the U.S. locomotive industry is Albert J. Churella's From Steam to Diesel: Managerial Customs and Organizational Capabilities in the Twentieth-Century American Locomotive Industry (Princeton: Princeton University Press, 1998).

${ }^{5}$ Hounshell, From the American System to Mass Production, chap. 5.

${ }^{6}$ For more on the unique social division of labor organized by wholesale merchants in the bicycle industry (known as an "assembly system"), see Johzen Takeuchi, The Role of Labour Intensive Sectors in Japanese Industrialization (Tokyo: United Nations University Press, 1991), chap. 4. 
The sectors that led the way in Japan's order-production, building type of machine industry included ships, railway rolling stock, and heavy electric machinery. These industries achieved rapid technological improvement and import substitution against the background of a very close relationship with powerful users or the national sector in infrastructure sectors needed for industrial development: marine transport, the railways, electrical power. From the Meiji period on, all these industries continued to rank at the top in terms of volume of production in their own areas of the machine industry, and they were the kind of industries in which large oligopolistic manufacturers led the way in those respective industries.

Within this order-production, building type of machine industry there were great differences among the processes of development in the manufacturing of machine tools and other industrial machinery, an area in which there is a relatively heavy preponderance of small and medium-sized businesses. If we look, for example, at the machine tool industry as it was between the two world wars, we see that its market showed a multilayered composition of: an imported machine monopoly, a concurrence of domestic-made and overseasmade machines, a domestic-made machine monopoly, and secondhand goods; responding to this market structure was a production structure on the supply side, with a multilayered composition ranging from the five major manufacturers to tiny producers. The subdivision of the market limited each manufacturer's scale of mass production, and when one compares the products of the major manufacturers and those of tiny producers, one finds such differences in price and performance that one cannot imagine them to be the same machine tools. ${ }^{7}$ Still, as far as the small and medium-sized makers were concerned, the domestic-made machine monopoly market, which could not be penetrated by imported machines, was the basis of their existence and at the same time the arena providing them with an opportunity to acquire and enhance technology. Rising one step at a time up the ladder of the multilayered production structure (a

${ }^{7}$ Minoru Sawai, "Kōsaku kikai kōgyō no jūsōteki tenkai-1920 nendai o megutte" [The multilayered development of the machine tool industry in the 1920s], in Ryōshin Minami and Yukihiko Kiyokawa, eds., Nihon no kögyöka to gijutsu hatten [Japan's industrialization and technological development] (Tokyo: Tōyō Keizai Shinpōsha, 1987). 
nontariff barrier, it might be said) was the normal process of business development for individual firms, and the sum total of such processes brought about technological improvement in the industry as a whole.

Within one and the same order-production, building type of machine industry, therefore, there were great differences to be found in the market and production structures and in the process of technological improvement in the two main classes of business: the large enterprises that rose to represent the industry at a comparatively early time, and the far greater number of small and medium-sized businesses that were forced to spend a long period of time rising, one rung at a time, up the ladder within the multilayered production structure. In order to understand the overall picture of the prewar machine industry in Japan as it tried to catch up with the more advanced industrialized countries, one must analyse the various industries that created these two development processes in an orderproduction, building type of machine industry and also the networks of a social division of labor-even to an extreme-in such industries as the bicycle industry.

It is for this reason that I wish in this study to take up the rolling stock manufacturing industry, as I believe knowing about it is indispensable for any consideration of the process of development of the order-production, building type of machine industry that existed in Japan as it tried to catch up with the industrialized world.

\section{THE ROLLING STOCK INDUSTRY AND THE DESIGNATED FACTORY SYSTEM}

The first railway to operate in Japan was the government-owned Japan National Railway (JNR), which began operating in October 1872 on a narrow-gauge track running between Shinbashi in Tokyo and Yokohama, a distance of 29 kilometers. At the time JNR owned ten steam locomotives, fifty-eight passenger cars, and seventy-five freight cars, all of them imported from England. ${ }^{8}$ The development of railways that was to follow was remarkable; after an initial boom in 1887-89 and a second boom in 1895-97, as of the end of 1900 the length of railway tracks in operation stood at $5,999 \mathrm{~km}$ (of which 1,325

\footnotetext{
${ }^{8}$ Hiroshi Kubota, Tetsurin no kiseki-tetsudō sharyō 100 nen no ayumi [Tracking iron wheels: One hundred years of rolling stock] (Tokyo: Taishō Shuppan, 1981), pp. 3, 11, and 16.
} 
$\mathrm{km}$ were owned by JNR and 4,674 $\mathrm{km}$ were owned by private railways). From 1889 the length of tracks in operation owned by private railways exceeded JNR's, and this ratio would not be reversed until the nationalization in 1906-1907, by which the government purchased seventeen of the main private railways. Through the nationalization program JNR took over from the private railways 1,118 locomotives, 3,067 passenger cars, 20,884 freight cars, and 48,409 workers, and by the end of the 1907 financial year it owned $91 \%$ of all the tracks being used in the whole country. ${ }^{9}$ Still, the private railways were not about to fade away; by the end of the 1930 financial year they had grown so much that their share of the nation's tracks had risen to $39 \% .10$

The steam locomotives that were used during the rapid expansion of railways in the Meiji period were almost all imported. Of the 2,377 steam locomotives held by JNR in 1912, 995 were of U.S. make, 983 were of British make, 226 were of German make, and only 162 (or $6.8 \%$ ) were of Japanese make. ${ }^{11}$ In the early stages the imports were all from England, but from 1893 to 1897 those made in America came to exceed those made in England, thanks no doubt to shorter waiting periods, relatively low prices, and a good ability to meet the demands of users, ${ }^{12}$ while imports of German-made locomotives took off after the Russo-Japanese War. The American companies Baldwin Locomotive Works and Schenectady Locomotive Works (later to become American Locomotive Co., or ALCO, with the amalgamation

${ }^{9}$ Masaho Noda et al., eds., Nihon no tetsudō-seiritsu to tenkai [Railways in Japan: Their establishment and development] (Tokyo: Nihon Keizai Hyōronsha, 1986), p. 121. For a long article in English on Japanese railways in the early days, see Francis $\mathbf{H}$. Trevithick, "The History and Development of the Railway System in Japan," Transactions of the Asiatic Society of Japan 22 (July 1894), pp. 115-252. For more in English on the railways, see the feature articles in volume 16 (1999) of Japanese Yearbook on Business History; the first feature article deals specifically with nationalization in England and in Japan.

${ }^{10}$ Ryōshin Minami, Tetsudō to denryoku [Railways and electric utilities]. Long-Term Economic Statistics, vol. 12. Tokyo: Tōyō Keizai Shinpōsha, 1965, p. 205.

${ }^{11}$ Nihon Kōgakukai, ed., Meiji kōgyō shi [The industrial history of the Meiji period] (Machinery and Earth Sciences Edition, 1930), p. 275.

${ }^{12}$ From the fact that, in 1899, twenty locomotives were sold to Burma by Baldwin Locomotive Works, which had bid at 1,750 pounds apiece and six months to deliver, while a British builder wanted 2,000 pounds apiece and eighteen months for delivery, I draw the conclusion that the Philadelphia company must have rapidly advanced into markets that had been the sole domain of British companies on the strength of low prices and short delivery periods. See J. K. Brown, The Baldwin Locomotive Works, pp. 46-47, 264. 
of eight manufacturers in 1901) and the British companies Dubs \& Co., Neilson Reid \& Co., North British Locomotive Co. (established through the amalgamation of three manufacturers in 1903), and Beyer Peacock \& Co., Ltd. each managed to export to Japan more locomotives than were produced in all of Japan during the Meiji period. ${ }^{13}$

In 1893 the first steam locomotive was produced at JNR's Kobe Works under the guidance of Richard Francis Trevithick (grandson of Richard Trevithick, known as the "father of locomotives"), and after this a small number of such locomotives continued to be produced, though intermittently, in factories of both the government-owned and the privately owned railways. Still, the technical level attained in the railway factories through the regular servicing and repair of rolling stock was considerably high, and the movement of the technicians and laborers working in those factories into private rolling stock companies meant that these railway factories functioned as catchment areas for the diffusion of rolling stock technology from the middle of the Meiji period.

The first private rolling stock company to produce a steam locomotive was Kisha Seizō Co. (KSC), which had been established in 1896 by a group of people led by Masaru Inoue, former chief of the Railway Bureau (Tetsudōchō), who was appointed president of the company. It began work on its first locomotive in July 1900, completing it in June of the following year. Before starting out on the project, it borrowed blueprints from the Shinbashi Works of the Railway Operations Bureau (Tetsudō Sagyōkyoku) and also hired a portion of its skilled workers from the same factory; in addition, it hired technicians from two private railway companies, the Japan Railway Co. and the Kansai Railway Co., for the purpose of improving design and production technology. ${ }^{14}$ Following in the footsteps of KSC came Kawasaki Shipyards, which had entered into rolling stock production during the shipbuilding recession that struck after the end of the Russo-Japanese War.

${ }^{13}$ Kubota, Tracking Iron Wheels, pp. 29-30, 56.

${ }^{14}$ See Editorial Committee for the Commemorative Book, ed., Kisha Seizō Kaisha jōki kikansha seizō shi [The history of steam locomotive manufacturing by KSC] (Tokyo, 1972), p. 41. The name of the government body in charge of the government railway, the JNR, was changed often in these early years, from Tetsudō-chō to Tetsudō Sagyōkyoku to Teikoku Tetsudō-chō (Imperial Railway Bureau) to Tetsudō-in, then between the two wars it was Tetsudō-shō (Ministry of Railways). 
In 1912 both these companies became designated factories of the Ministry of Railways (Tetsudō-in, read JNR), and this led to these two companies monopolizing the production of locomotives for JNR operations.

Since the production of passenger and freight cars is easy compared to locomotives, it was possible to produce the bodies of the carriages by using traditional woodworking technology while relying on the import of principal parts, and domestic self-sufficiency in regard to passenger and freight car bodies had more or less been achieved shortly after the Sino-Japanese War. The three best-known passenger and freight car manufacturers were KSC, Kawasaki Shipyards, and a company that had been founded in Nagoya in 1896, Nippon Sharyō Seizō Co. (NSS). At a time when top-level technicians were hard to find, this last-named company treated its chief engineer very generously indeed, giving him a monthly salary that was twice that received by the president of the company.15

The nationalization of the railways in 1906-1907 was very important in that it forced the major rolling stock companies to look at wideranging changes in their past business policies. Nationalization meant that the leading private railways had disappeared and JNR was now the largest user of what they produced, but at that stage the situation did not mean that these companies would now be guaranteed large deliveries to the JNR every year without fail. It was with this concern in mind that, in August 1909, the three largest suppliers of rolling stock to JNR-KSC, NSS, and Kawasaki Shipyards-organized a cartel by the name of Tetsudō Yōhin Seizō Kyōdō Jimusho (Joint Office for the Manufacturing of Railway Supplies), whose purpose was joint acceptance and reasonable apportionment of orders for rolling stock (principally) for JNR. ${ }^{16}$

JNR, on its part, established a policy in 1909 of ordering as much as possible the majority of the locomotives and passenger cars it needed from private rolling stock manufacturers within Japan, and what it conceived of at the time as the requisite infrastructure was this

${ }^{15}$ Nippon Sharyō Seizō, ed., Nippon Sharyō Seizō hachijūnen no ayumi-bakushin [An eighty-year history of NSS: Making a dash for it] (Nagoya: NSS, 1977), pp. 14-15.

${ }^{16}$ For more on this cartel, see Naosuke Takamura, "Dokusen soshiki no keisei" [he formation of oligopolistic organizations], in N. Takamura, ed., Nichi-Ro sengo no Nihon keizai [The Japanese economy after the Russo-Japanese War] (Tokyo: Hanawa Shobō, 1988), pp. 168-77. 
Joint Office for the Manufacturing of Railway Supplies. The decision to procure its rolling stock from within the country rather than from countries overseas was prompted by the fact that after the conclusion of the Russo-Japanese War the government was forced to undertake very strict financial management as a result of the burden it faced of repaying principal and interest on the foreign debt it had amassed in order to finance that war.

There was lobbying by the private rolling stock manufacturing companies as well, and so in 1912 JNR made a decision basically to purchase all new rolling stock from the following year only from the three designated factories (to which was added later a fourth, Amano Works), and this applied to locomotives as well: no locomotives would be imported. ${ }^{17}$ In this way was formed in the rolling stock industry an oligopolistic system of a body of designated factories composed of four principal companies. In February 1912, once the designated factory system was clearly in place, the Joint Office for the Manufacturing of Railway Supplies would be dissolved. This was because the cartel function that the Joint Office had fulfilled up till then had been subrogated by the designated factory system.

On the basis of the domestic self-sufficiency policy of 1909 and the introduction of the designated factory system in 1912, JNR opted for dividing the labor between the government and the private sectors according to the following arrangement: JNR factories would handle servicing and repair, private designated factories would handle construction of new rolling stock. The problem was the existence of a large technological gap between, on the one hand, the manufacturing capacities and technical levels of the designated factories and, on the other hand, the rolling stock standards that JNR expected; this was especially true in regard to the mass production system for locomotives. Consequently, the goal of self-sufficiency measures from then on was set at eliminating this technological gap in as short a space of time as possible.

JNR provided the designated factories with a variety of technological assistance. The basic blueprints for locomotives were produced by JNR, and these were given to the designated factories free of charge; in addition, a portion of the required materials were bulk purchased by

${ }^{17}$ The History of Steam Locomotive Manufacturing by KSC, p. 34; An eighty-year history of NSS, p. 78. 
JNR and given to the private manufacturers; also, JNR engineers were permanently stationed at the production sites of designated factories to serve as production supervisors. ${ }^{18}$ Other measures were taken as well: in order to help workers in designated factories to acquire the concrete know-how needed to manufacture locomotives, Kawasaki Shipyards and KSC engineers were made to measure the sizes and accuracy of every part of a locomotive that JNR had imported, and once they had done that, they had to build duplicates of the imports in their respective companies. ${ }^{19}$

As a result of such systematic technical assistance and guidance from the JNR, by the time of World War I the level of the design and production technology in the designated factories was such that it more or less satisfied JNR's demands. Parallel with these improvements, legislation on standards for rolling stock parts had also made progress, and all the conditions for moving into mass production were gradually falling into place. Still, even though technical improvements had been realized, as far as prices went, there remained a gap between domestically produced locomotives and those imported from the United States or Germany, and this was due to the limitations of the scale of mass production and the need to rely on importation of the principal parts and of materials. This price difference was eliminated by the 1911 revision of tariffs. ${ }^{20}$

The significance to the designated factories of the establishment of the designated factory system was not limited to technical assistance from JNR and revision of tariff regulations. Thus, in the case of NSS for example, prior to its becoming a designated factory its factory profit ratio for rolling stock manufactured for private and other railways surpassed that for rolling stock manufactured for JNR, but in the years 1913 and 1914 this was reversed..$^{21}$ By becoming a designated factory,

${ }^{18}$ Shigenobu Usui, Kikansha no keifuzu [A genealogical table of locomotives] (Tokyo: Kōyūsha, 1978), vol. 4, p. 478.

${ }^{19}$ Commemorative Committee for the Bicentennial Anniversary of James Watt's Birth, ed., Zusetsu Nihon jōki kōgyō hattatsu shi [Illustrated history of the development of Japan's steam industries] (Tokyo, 1938), p. 174.

${ }^{20}$ Ministry of Agriculture and Commerce, ed., Shuyō kōgyō gairan [Survey of major industries] (Tokyo, 1912), pp. 395-96.

${ }^{21}$ Nippon Sharyō Seizō, Kessan shohyō [Statement of accounts], each term. 
therefore, NSS was guaranteed a large volume of orders and stable high profits, both of which paved the way for its later growth.

THE ROLLING STOCK INDUSTRY BETWEEN

THE TWO WORLD WARS AND THE MANCHURIAN MARKET

When World War I broke out, the importation of raw materials and parts for railway rolling stock was interrupted, not only from Germany, a belligerent country, but also from England; at the same time, the importing of raw materials and parts from a country Japan began to rely on for such goods, the United States, started to require much longer delivery time, and the prices registered a sudden jump. These difficulties in procuring imported goods acted as a stimulus to achieve domestic self-sufficiency in all raw materials and parts connected with railway rolling stock, and as a result rapid progress was made from the World War I years into the early 1920s in the production within Japan of wheels, axles, springs, seamless pipes, steel and cast steel parts, and other requirements. By the early 1920s the only task remaining for complete self-sufficiency was the production of such items as electric locomotives, motors, controllers, and air brakes.

In 1925 the Ministry of Railways (Tetsudō-shō) developed an MT15-type motor through a joint design with three private companies: Shibaura Works, Ltd., Hitachi Works, Ltd., and Tōyō Denki Seizō Co. ${ }^{22}$ In the course of this joint design project a very close technological exchange between makers and users was realized, and this kind of joint design format became the model for future measures aimed at developing new technology and replacing imports. Domestic self-sufficiency in air brakes would be attained by having Nippon Air Brake Co. and Mitsubishi Denki Co. enter a technological tie-up with Westinghouse Air Brake Co., and then joining JNR in a joint design project in 1927 and 1928, as a result of which the standard type air brake for passenger cars was decided on. ${ }^{23}$

${ }^{22}$ Kiichi Asakura, "Testudō-shō denshayō 100 kw dendōki no tōitsu ni tsuite" [On the unification of 100-kilowatt motors for electric cars of the Ministry of Railways], Kögyō zasshi [Journal of Industry] 61 no. 779 (1925), p. 538.

${ }^{23}$ Nippon Air Brake Co., ed., Nippon Eya Bureeki sanjūnen shi [A thirty-year history of Nippon Air Brake] (Kobe, 1955), pp. 5-14; Mitsubishi Denki Co., ed., Mitsubishi Denki shashi [Company history of Mitsubishi Electric Corporation] (Tokyo, 1982), p. 434; and 
During the 1920s, as can be seen, JNR evolved a variety of technological policies. But perhaps the one that best symbolized the high level to which they were raised was the Conference on Rolling Stock. This began in 1922 as an event held once a year, but from 1925 it began to be held twice a year; by 1942 there had been nineteen conferences devoted to the topic of locomotives and seventeen devoted to the topic of passenger and freight cars or to both types of rolling stock considered jointly. ${ }^{24}$ The sponsor of the conferences was the Rolling Stock Section, Bureau of Manufacturing, in the JNR; this section was made up of elite engineers who had graduated from imperial universities, and it controlled JNR's technological policies in regard to rolling stock.

It was not only JNR personnel who attended the conferences. Quite the contrary: the conferences brought together representatives from the designated factories, parts makers, material suppliers and manufacturers, the South Manchuria Railway Co., the Korean and Formosan government railways, and the leading private railways from all parts of Japan-engineers and technicians who had any conceivable connection with railway rolling stock. The activities of these conferences, every one of which was attended by close to 70 to 100 engineers and technicians from the public and private sector, were not limited to the period of a few days during the actual conferences themselves. Every topic for discussion was decided upon one year in advance, ${ }^{25}$ and those in charge of the conferences conducted field tests and research on the given research topics at actual sites, such as factories, manufacturing plants, and research institutes of the various participating members, and then presented an assessment of the cumulative results of these tests and research at the subsequent conference. Any items decided upon at the conference were immediately put into effect by JNR. ${ }^{26}$

Though the conferences on rolling stock were naturally occasions on which JNR exercised the function of organizer, they very closely

Japanese National Railways, ed., Nihon Kokuyū Tetsudō hyakunen shi [One hundred years of JNR] (Tokyo, 1972), vol. 9, p. 526.

${ }^{24}$ Kubota, Tracking Iron Wheels, p. 107.

${ }^{25}$ Bureau of Manufacturing of JNR, ed., Dai-yonkai Sharyō Kenkyūkai kiroku [Records of the 4th Conference on Rolling Stock] (Tokyo, 1925), p. 16.

${ }^{26}$ Japanese National Railways, ed., One Hundred Years of JNR, vol. 9, pp. 446-53. 
approximated settings for joint research by users and manufacturers on a common task. Reflecting the improvement in the technological level of the private-company designated factories, the conferences thus were no longer occasions for a unilateral transfer of technology from JNR to the designated factories, as was the case at the time of the birth of the designated factory system. This trend was especially noticeable in joint design; participants in joint design pushed on towards the realization of the common objective of domestic production on an equal footing.

More than anything it was the existence of large-volume orders from JNR producing long-term, stable high profits that afforded the greatest basis upon which the rolling stock industry, out of all the machine industries, attained technological independence from overseas sources at the earliest point in time (and about the same time as the shipbuilding industry), and made it possible for the business operations of the principal rolling stock enterprises to undergo stable transitions. But then the Great Depression came along and domestic demand plunged; furthermore, recovery was a long time in coming, and, in the case of locomotives, it would not be until after 1935 that 1929 levels were surpassed. ${ }^{27}$ The rolling stock manufacturing industry, which had built itself upon a foundation of sales to JNR, faced its greatest test since the establishment of the designated factory system at the end of the Meiji period.

What saved the industry from this business crisis was the appearance of an enormous demand from Manchuria following upon the outbreak of the Manchurian Incident in September 1931. On the basis of an agreement with the government of Manchukuo and the Kwantung Army, the South Manchuria Railway Co. not only operated its own lines but also was entrusted with the Manchukuo National Railways. This meant it required a huge amount of rolling stock for the purpose of economically developing Manchuria, which now was incorporated under Japan's control.

A breakdown of the total number of steam locomotives produced for Manchuria for the period from 1933 to 1937 shows that KSC produced 174, Kawasaki Sharyō Co. produced 173, Hitachi Works, Ltd.

${ }^{27}$ Tōyō Keizai Shinpōsha, ed., Shōwa sangyō shi [The history of industries in the Shōwa period/ (Tokyo: Tōyō Keizai Shinpōsha, 1950), vol. 1, p. 303. 
produced 150, and NSS produced 90. ${ }^{28}$ Except for Kawasaki Sharyō, all of the other three companies produced more locomotives for Manchuria than they did for JNR during the same period. ${ }^{29}$ For the designated factories, prior to the outbreak of war between Japan and China in 1937 the situation had already been reached in which running the businesses was unthinkable without the orders coming in from the South Manchuria Railway.

The manufacture and delivery of rolling stock for the South Manchuria Railway and the Manchukuo National Railways was, as in the case of JNR, placed under the strict supervision of South Manchuria Railway inspectors. Rolling stock parts to be produced by private subcontractors were designed at the South Manchuria Railway's Bureau of Manufacturing; in certain cases standardized components that the Bureau of Manufacturing, in-house factories, and the Institute of Railway Technology had jointly researched and trialproduced would be handed over to the manufacturers. ${ }^{30}$ In addition, South Manchuria Railway supervisors were permanently stationed at the designated factories, whose job it was to supervise the production processes and inspect the manufactured goods. ${ }^{31}$ Moreover, the orders placed with the South Manchuria Railway's designated factories, like those placed with JNR and the government-run railways in Korea and Taiwan, came with the main materials and parts supplied. ${ }^{32}$ South Manchuria Railway had representatives taking part in the Conference on Rolling Stock programs, and in this way it not only deepened technological exchanges with JNR, the government-run

${ }^{28}$ The rolling stock division of Kawasaki Shipyards was set up as a separate company-Kawasaki Sharyō-in 1928.

${ }^{29}$ See The History of Steam Locomotive Manufacturing by KSC, Appendix, and Hajime Watanabe, Nihonsei kikansha seizō meiban shüsei [A list of locomotives manufactured in Japan] (Nagoya: Privately published, 1982), pp. 34, 44-46, 60-61, 98-101.

${ }^{\text {s0 } Y o s h i z u m i ~ I c h i h a r a ~ e t ~ a l ., ~ e d s ., ~ M i n a m i ~ M a n s h u ̄ ~ T e t s u d o ̄: ~ " A j i ̈ " ~ t o ~ k y a k u k a s h a ~ n o ~ s u b e t e ~}$ [South Manchuria Railway: "Asia" and all about passenger and freight cars] (Tokyo: Seibundō Shikōsha, 1971), p. 219.

"Shigeru Ishikawa, Kunan no michi [A thorny path] (KSC, no date), the volume on Tokyo Works, Shōwa period (7).

${ }^{32}$ Nichi-Man Zaisei Kenkyükai, "Honpō keizai kokuryoku handan (dai-yoji hōkoku)" [A survey of the economic power of Japan (4th Report)], dated 7 February 1940, in Takafusa Nakamura and Akira Hara, eds., Gendai-shi shiryō 43—kokka sōdōin 1 [Sources of contemporary history 43: Total mobilization 1] (Tokyo: Misuzu Shobō, 1972), p. 92. 
Korean and Taiwan railways, and the manufacturers of rolling stock and their parts, but it also took the relationship between JNR and JNR's designated factories as the model for its relationship with its own designated factories.

The five principal companies within the South Manchuria Railway designated factory system were Kawasaki Sharyō Co., KSC, NSS, Hitachi Works, Ltd., and Tanaka Sharyō Co. These five formed an order-receiving cartel called the Yayoikai, whose aim was mutual cooperation; ${ }^{33}$ at the same time, Kawasaki Sharyō was using Mitsubishi Corporation as its agent, KSC was using Ōkura \& Co., and NSS was using Mitsui \& Co. ${ }^{34}$ The founding of the Manchurian Rolling Stock Co. epitomizes the cooperative activities of the Yayoikai. Moves to found Manchurian Rolling Stock Co. originated with some strong pressure from the Kwantung Army and the South Manchuria Railway directed at the Yayoikai in 1936. This was followed in April 1937 by the start (on the Japanese mainland first of all) of a five-year plan for industrial development in Manchuria, and with the implementation of this industrial development plan in view, South Manchuria Railway not only expanded its in-house factories but also made strong requests to the Yayoikai to establish a new company in Manchuria. The Yayoikai, for its part, was at first hesitant about direct investment in Manchuria, but it was unable to continue rebuffing the repeated requests, ${ }^{35}$ and in June 1937 it came up with a concrete plan for the establishment of a company. ${ }^{36}$ Thus it came to be that in May 1938, after the start of hostilities between Japan and China, the Manchurian Rolling Stock Co., capitalized at five million yen, was established in Feng Tian (present-day Shen Yang). Even though relying mainly on the Yayoikai member companies, the company was jointly funded as well by materials producers, parts makers, and other major companies connected with rolling stock production. The domestic rolling stock companies would take the opportunity provided by the founding

\footnotetext{
${ }^{39}$ Mitsubishi Corporation, ed., Ritsugyō bōeki roku [The history of international trade as the main business] (Tokyo, 1958), p. 258.

${ }^{34}$ Hidekata Aida, Taiki monogatari [The story of Da-lian Engineering Works] (Tokyo: Daitoku Shōji, 1957), p. 41.

${ }^{95}$ Kisha Seizō Co., ed., KSK nenpyō chī 1 [A chronological table of KSC: Footnotes no. 1] (no date), p. 1241.

${ }^{36}$ Ibid., p. 1242.
} 
of Manchurian Rolling Stock Co. to deepen their ties with the Chinese mainland.

THE ROLLING STOCK INDUSTRY DURING WARTIME

As the war between Japan and China progressed, the organization of an "economic bloc of Japan, Manchuria, and China" was declared, and in that bloc rolling stock held an extremely important position as a key means of wartime transport in Japan proper, its colonies, and its occupied territories. The manufacturing of rolling stock was designated one of the industries crucial to a plan for expansion of production capacity, and in July 1939 the Council on Rolling Stock was set up in the Planning Board, its membership to include JNR, the Ministry of Commerce and Industry, South Manchuria Railway, the government-run railways in Korea, Taiwan, and Karafuto (Sakhalin), North China Transport Co., and Central China Railway; its purpose was to act as a body to regulate the production and distribution of rolling stock for the whole of the "economic bloc of Japan, Manchuria, and China," and thus for Japan, Korea, Taiwan, Sakhalin, Manchuria, North China, and Central China. Within the Council on Rolling Stock production plans were decided quarterly for every railway rolling stock user, and an allotment of materials was also made for rolling stock destined for private railways. ${ }^{37}$

The manufacturers had their own associations, too. In July 1938 a Council on Materials for Rolling Stock (Tetsudō Sharyō Yōzai Kyōgikai) was formed from member companies of JNR's designated factories; its function was to oversee the supply of materials other than those allotted to the companies byJNR. In December 1939 the Council was reorganized as the Japan Association of Rolling Stock Manufacturers (Nihon Tetsudō Sharyō Seizō Kōgyō Kumiai). As part of the reorganization, the materials distribution function of the Yayoikai was absorbed by the Association, with the result that, at least as far as the distribution of materials to domestic makers was concerned, a unified regulation of what went back and forth between Japan and

${ }^{37}$ Matsuyoshi Iwasaki, Kokudo keikaku, zōsen, sharyō kōgyō [National land planning, shipbuilding, and the rolling stock industry] (Tokyo: Itō Shoten, 1941), p. 288, and Masanosuke Tsuzaki, Wagakuni no tetsudō sharyō kōgyō [The rolling stock industry in Japan] (Tokyo: Koronasha, 1950), pp. 350-51. 
Manchuria was put into place. The Japan Association of Rolling Stock Manufacturers was made up of a total of twenty-six companies, from rolling stock manufacturers to parts and material producers; its main functions were materials distribution, production adjustment, and the monitoring of production achievements. Finally, in December 1941 another organization was established for the purpose of integrating the Association and other related industrial associations; this was the Rolling Stock Control Association (Sharyō Tōseikai), composed of ninety members, and it was the principal instrument of control during the Pacific War. ${ }^{38}$

Like most of the other industries for whom production capacity expansion was planned, the rolling stock industry recorded a peak in production in fiscal 1940 and then showed production declines in the 1941 and 1942 fiscal years, but, unlike the other industries, it then rebounded in the 1943 and 1944 fiscal years. No other industry could claim the same distinction. ${ }^{39}$ As Japan's war situation deteriorated, the military was forced to transport more and more vital materials by land rather than by sea, and a Cabinet decision in July 1943 guaranteed that the rolling stock industry would be given the same treatment as the "Five Major Industries" (steel, coal, light metals, shipbuilding, and aircraft manufacturing), and this is what supported the increase in production during the later stages of the Pacific War. ${ }^{40}$ Another thing that contributed to increased production of rolling stock was the system of consigned purchase by JNR. This system, which began operating in 1942, was an expansion of the earlier system whereby JNR granted materials to its designated factories; in the new system, after receiving a request from a designated factory for steel materials needed for production, JNR procured these in place of the private sector manufacturer. At a time in the war when there was fierce competition from the Army, Navy, and shipbuilding industry to procure materials, this system of entrusting the procurement of steel materi-

${ }^{38}$ Iwasaki, National Land Planning, Shipbuilding, and the Rolling Stock Industry, pp. 288-91; Tsuzaki, The Rolling Stock Industry in Japan, pp. 350-51; Asahi Shinbunsha, ed., Asahi Keizai Nenshi [Asahi Economic Yearbook] (Osaka: Asahi Shinbunsha, 1943), p. 139. 305.

${ }^{99}$ Tōyō Keizai Shinpōsha, ed., The History of Industries in the Shōwa Period, vol. 1, p.

${ }^{40}$ Japanese National Railways, ed., One Hundred Years of JNR (Tokyo, 1973), vol. 10, pp. 76-77. 
als to JNR-of letting JNR be the front for them-alleviated the difficulties private sector manufacturers would have had in procuring materials. ${ }^{41}$

Despite all this, if we look at the fluctuations in the ratio of factory profit for NSS during the hostilities between Japan and China, we find a rapid deterioration compared to the period preceding hostilities. The main reason for the deterioration in profit ratio was a continuing low level of profit from sales to NSS's key customers, JNR and Mitsui \& Co., caused by the rapid rise in the price of raw materials as compared with movements in the finished goods (contracted) price. In October 1937 NSS's Inchon Works in Korea began production, but more than half of Inchon Works rolling stock sales to the Korean government's railway were at a loss, the result of the contracted price being too low, and NSS was making up for those losses through sales to private railways and exclusive lines. ${ }^{42}$

When the Pacific War began, the business tribulations of major rolling stock companies increased. At KSC, worker mobility soared; adding to the company's woes were the continuing cases of long-term absenteeism (resulting from workers' taking on temporary jobs at other factories). ${ }^{43}$ The dispersal of subcontracting factories was yet another big problem; the number of subcontracting factories of KSC's Osaka Works, for example, fell from 89 factories (located within Osaka Prefecture) at the end of May 1943 to 43 by the end of January 1945.44 To these problems with materials, labor, and subcontractors was added, in the later stages of the Pacific War, difficulties in producing weapons. In the second half of fiscal 1943, for example, to comply with an order from the military, Hitachi Works, Ltd. started producing special transport vessels at its Kasado Works. Even though the Army, envisaging mass production of these transport vessels, put in an

${ }^{41}$ Tōyō Keizai Shinpōsha, ed., The History of Industries in the Shōwa Period, vol. 1, p. 318.

${ }^{42}$ Nippon Sharyō Seizō, Kessan shohyō [Statement of accounts], each term.

49 Nihon Sangyō Keizai shinbun, 20 October 1943.

${ }^{44}$ Hiroshi Ueda, "Senjiki Ōsaka ni okeru shitaukesei no tenkai (1)—'Kyōryoku kōjō meibo' bunseki o chūshin ni" [The development of the subcontracting system in wartime Osaka (1): An analysis of the "List of Subcontracting Factories"] , Kikan keizai kenkyū (of Osaka City University) 15, no. 1 (June 1992), p. 18. 
order for 400 of them to be built, by the end of the war only 26 had been launched. ${ }^{45}$

On the Chinese mainland, the founding of the Manchurian Rolling Stock Co. in May 1938 was followed in June 1940 by the founding of North China Rolling Stock Co. This company was also funded jointly by the major firms connected with the rolling stock industry in Japan. And just as the Manchurian Rolling Stock Co. was established because of strong urging by the Kwantung Army, so the North China Rolling Stock Co. was established because of strong pressure from the North China Expeditionary Army. There was one major difference, however: the difficulty of the situation surrounding the latter company at the time of its founding was beyond comparison. There were not enough machines and equipment, raw materials were hard to come by; limited by these factors, production at the company did not proceed according to plan. ${ }^{46}$

\section{CONCLUSION}

As should be clear by now, what the various technological policies of JNR were by and large aimed at (assuming strong links between users and makers under the artificially partitioned competitive condition of the designated factory system) were the reproduction and sustenance, on a policy level and in a conscious manner, of all the factors that would give rise to the technological innovation that would normally be involved in the very process of free competition among enterprises. JNR's method of selecting certain outstanding factories towards the end of the Meiji period and protecting and nurturing them in a concentrated manner was an extremely effective method of catching up when resorted to for a short time or slightly longer; the private sector enterprises selected also responded well to the demands put upon them. Still, it proved difficult to ward off completely the bureaucratization and hardening of management that are pro-

${ }^{45}$ Hitachi, Ltd., ed., Kasado kōjō shi [The history of Kasado Works] (Kudamatsu: Hitachi, Ltd., 1975), pp. 48-49.

${ }^{46}$ The North China Rolling Stock Co., ed., Kessan hökokusho [Statement of accounts], each term. 
duced when such stable relationships of protection and nurture continue for a long time.

A relationship between one or a few users with a high degree of technological capability and a limited number of makers was not limited to the railway rolling stock industry in prewar Japan. Similar relationships existed in the shipbuilding industry between the Japanese Navy and Mitsubishi and Kawasaki Shipyards; in the aircraft industry between the Army and Navy and Mitsubishi Heavy Industries, Ltd. and Nakajima Aircraft Co.; and in the machine tool industry between the Army, Navy, and JNR and the five major manufacturers. Nevertheless, examples of relationships in which stable and large-volume demand continued to be presented over a long period of time, and in which diverse forms of technological policies were systematically developed in response to progress by the makers in accumulating technical prowess, as happened with JNR, were extremely rare.

Diversity in the development of machine industries in a country trying to catch up with more advanced industrial countries is restricted by such things as market scale, the ease or difficulty of design and production technology itself, and the development of related industries, but, at least in the case of order production, along with these conditions there is another important factor: the concrete relationship between users and makers. The development of the rolling stock industry gives some indication of how the process of absorbing, entrenching, and developing design and production technology can be greatly affected by the type of relationship that exists. 